\title{
ワルファリン至適治療域での抜歯に関する検討
}

\author{
吉川博政 ${ }^{1)} \cdot$ 樋口 崇 ${ }^{1)} \cdot$ 福元 俊輔 ${ }^{1)}$ \\ 吉田将律 ${ }^{1)}$ ・山本千佳 ${ }^{1)}$ ・樋口勝規 ${ }^{2)}$
}

\section{Clinical study of tooth extraction in patients receiving warfarin under optimal anticoagulation conditions}

\author{
YOSHIKAWA Hiromasa $^{1)} \cdot$ HIGUCHI Takashi $^{1)} \cdot$ FUKUMOTO Shunsuke $^{1)}$ \\ YOSHIDA Masanori $^{1)} \cdot$ YAMAMOTO Chika $^{1)} \cdot$ HIGUCHI Yoshinori ${ }^{2)}$
}

\begin{abstract}
The purpose of this study was to clarify whether tooth extraction in accordance with the JCS2004 guidelines has any problems. A total of 213 patients (429 teeth) who were receiving anticoagulant therapy with warfarin and required tooth extraction were examined between 2000 and 2008. The study group comprised 123 men and 90 women. The average age of the patients was 66.8 years, and a total of 429 teeth were extracted. The mean International Normalized Ratio (INR) of the patients and was 1.85 before publication of the JCS2004 guidelines and 2.15 after publication. This difference in the INR was significant $(\mathrm{p}<0.01)$. Before 2004, 37 of 55 patients underwent tooth extraction after stopping warfarin, and 3 had postoperative hemorrhage. After 2004, 144 of 158 patients underwent tooth extraction while continuing warfarin. The mean INR value at the time of extraction was 2.03 , significantly higher than the value of 1.48 before 2004 . There was no increase in postoperative hemorrhage. Bleeding complications in association with the continuation of warfarin also did not occur. The JCS2004 guidelines recommend maintaining the INR at 1.6 to 3.0, while excluding some patients. Our results suggest that tooth extraction can be done safely in association with the continuation of warfarin therapy if the patient's INR is controlled under optimal anticoagulation conditions.
\end{abstract}

Key words: warfarin (ワルファリン), tooth extraction (抜柬), JCS2004 guidelines (2004 年日本循環器学会ガイド ライン), optimal anticoagulation conditions（至適治療域), International Normalized Ratio (INR)

緒

抗血栓療法中に, 拔菌などの口腔外科処置を実施する際, 抗血栓療法薬を継続投与するか, 一時休薬するべきかとい う問題が生じる. 抗血栓療法を継続すれば出血性合併症の

1) 国立病院機構九州医療センター柬科口腔外科 (主任：吉川博政医長)

国立病院機構九州医療センター臨床研究センター (主任：村中 光研究センター長)

2) 九州大学病院口腔総合診療科 （主任：樋口勝規教授）

${ }^{1)}$ Department of Dentistry, Oral and Maxillofacial Surgery, National Hospital Organization Kyusyu Medical Center (Chief: YOSHIKAWA Hiromasa)

Clinical Research Institute, National Hospital Organization Kyusyu Medical Center (Chief: MURANAKA Toru)

${ }^{2)}$ Department of General Oral Care, Kyusyu University Hospital (Chief: Prof. HIGUCHI Yoshinori)

受付日：2009年 3 月 12 日

採択日：2010年 4 月 27 日
発現が䯚念され，中止すれば脳梗塞などの血栓症あるいは 塞栓性疾患の発症や再発が危惧される ${ }^{1,2)}$.

近年, 抜茵に関しては, ワルファリン継続投与下での処 置が可能との報告 ${ }^{3 \sim 6)}$ が多く, 欧米では抗血栓療法下で 行うとする見解が一般化しつつある ${ }^{7 \sim 9)}$. ワルファリン 休薬時の塞栓症など, 重篤な合併症を回避するため, 本邦 でも 2004 年に日本循環器学会から公表された抜茵時の抗 血栓療法に関するガイドライン ${ }^{10)}$ で「抜茵はワルファリ ンを原疾患に対する至適治療域にコントロールした上で, ワルファリン内服継続下での施行が望ましい」と記されて 打り，ワルファリン継続下での抜菌が推奨されている。し かし, 本邦ではガイドラインに示されたワルファリン至適 治療域での抜茵の安全性に関する研究は少ない 3,4$)$.

今回, 当科で実施したワルファリン服用患者の抜菌症例 を 2004 年の日本循環器学会ガイドライン公表前後の症例 で後ろ向きに調査し, 至適治療域のワルファリン継続投与 下での抜㐘の安全性について検討した. 


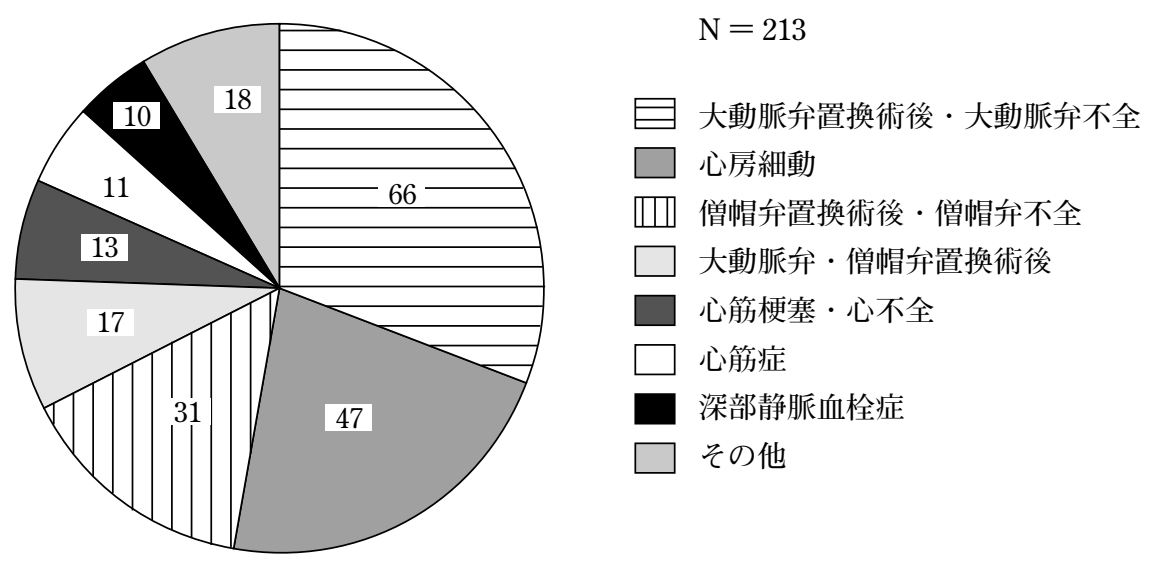

図 1 対象症例の基礎疾患

\section{対象 ・ 方 法}

対象は 2000 年 1 月から 2008 年 12 月までの 9 年間に国 立病院機構九州医療センター歯科口腔外科にて抜柬を受け た 218 例のワルファリン服用患者のうち抗血栓効果を INR 值（国際標準比：International Normalized Ratio）で評価 し得た 213 例（男性 123 名, 女性 90 名, 平均年歯 66.8 歳) 429 㐘である。主な基礎疾患としては，大動脈弁置換術 後・大動脈弁不全症 66 名, 心房細動 47 名, 僧帽弁置換術 後 - 僧帽弁不全症 31 名, 大動脈弁 - 僧帽弁置換術後 17 名, 心筋梗塞 - 心不全 13 名，心筋症 11 名，深部静脈血栓症 10 名, その他として腹部大動脈瘤, 脳梗塞, 肺塞栓症など 18 名であった（図 1). 抜㐘の原因疾患は，根尖性柬周炎 161 柬，辺縁性柬周炎 138 㐘，う蝕 127 柬，下顎智柬周囲炎 3 柬である. 抜㐘本数は 1 本が 100 例, 2 本が 44 例, 3 本が 33 例, 4 本が 14 例であり, Giovanni ${ }^{7)}$ らの分類による出血 の危険性が高くなる 5 本以上の抜歯は 16 例，骨膜を剥離 し，骨を開削した難抜柬が 3 例，下顎埋伏智柬抜柬が 3 例 であった。

抗血栓効果の程度は，INR值（国際標準比：International Normalized Ratio）にて評価した. 2004 年に日本循環器学 会から「循環器疾患に打ける抗凝固・抗血小板療法に関す るガイドライン」が公表され，各疾患に対する治療域が INRで示されたが，それ以前，すなわち 2003 年までは未だ INR での治療域が不明確で，抜柬の際ワルファリンを中止 すべきか継続すべきかの見解も統一されていなかった．そ こで当時われわれは本院心臓外科と協議し，2000～ 2002

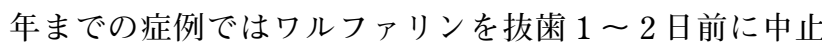
し, INR $1.3 \sim 2.0$ の範囲内で抜㐘を行った. 2003 年の症例 では，治療域が INR 2.0 以下であればワルファリン継続投 与下に抜菌した. 2004 年以降の症例は原則としてガイドラ
インで定められた至適治療域に管理された状態で，ワルフ アリン継続投与下に抜茵を行った.

\section{1 . 対象症例の抜歯前，抜歯時の INR 值の検討}

対象症例をガイドラインが公表される以前の 2000 2003 年までの症例（以下 2004 年以前群： 55 例, 110 柬), および公表後の 2004 ～ 2008 年までの症例（以下 2004 年 以降群：158 例，319柬）の 2 群に分け，至適治療域でコ ントロールされた症例の割合, 初診時または抜㐘前 1 か月 以内での INR 值について比較検討した。さらに抜歯前 6 時 間以内の INR 值についても同様に 2 群に分けて比較した.

\section{2. 抜歯後出血と合併症について}

2004 年以前群と以降群に分け，抜㐘後出血および合併症 の有無について調査した。また至適治療域にコントロール されている場合とされていない場合でワルファリン使用の

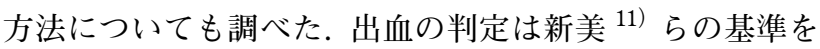
用いた。

抜㐘はいずれの症例も入院下に行った，心内膜炎予防が 必要な場合は術前にセファゾリン $1 \mathrm{~g}$ の静脈内投与を行っ た. 局所麻酔は 8 万倍エピネフリン含有 $2 \%$ キシロカイン を用い，基礎疾患の内容によって 24 万倍に希釈したエピ ネフリン含有 $2 \%$ ネロロインまたはフェリプレッシン含 有 $3 \%$ タネストオクタプレッシンも使用した。抜㐘後は 㐘肉縁部軟組織の不良肉芽を十分掻爬し，抜㐘窩にゼラチ ン製剂を填入後，創は 3-0 絹糸で密に縫合閉鎖，止血床は 使用せずガーゼのみで圧迫止血した。術後はセフェム系抗 菌薬を 3 日間投与した。

統計学的解析は 2004 年以前群と 2004 年以降群の 2 群間 で抜柬前，抜㐘時の INR 值については Student's t-test を用 い， 2 群間での抜柬後出血，合併症が発現については 


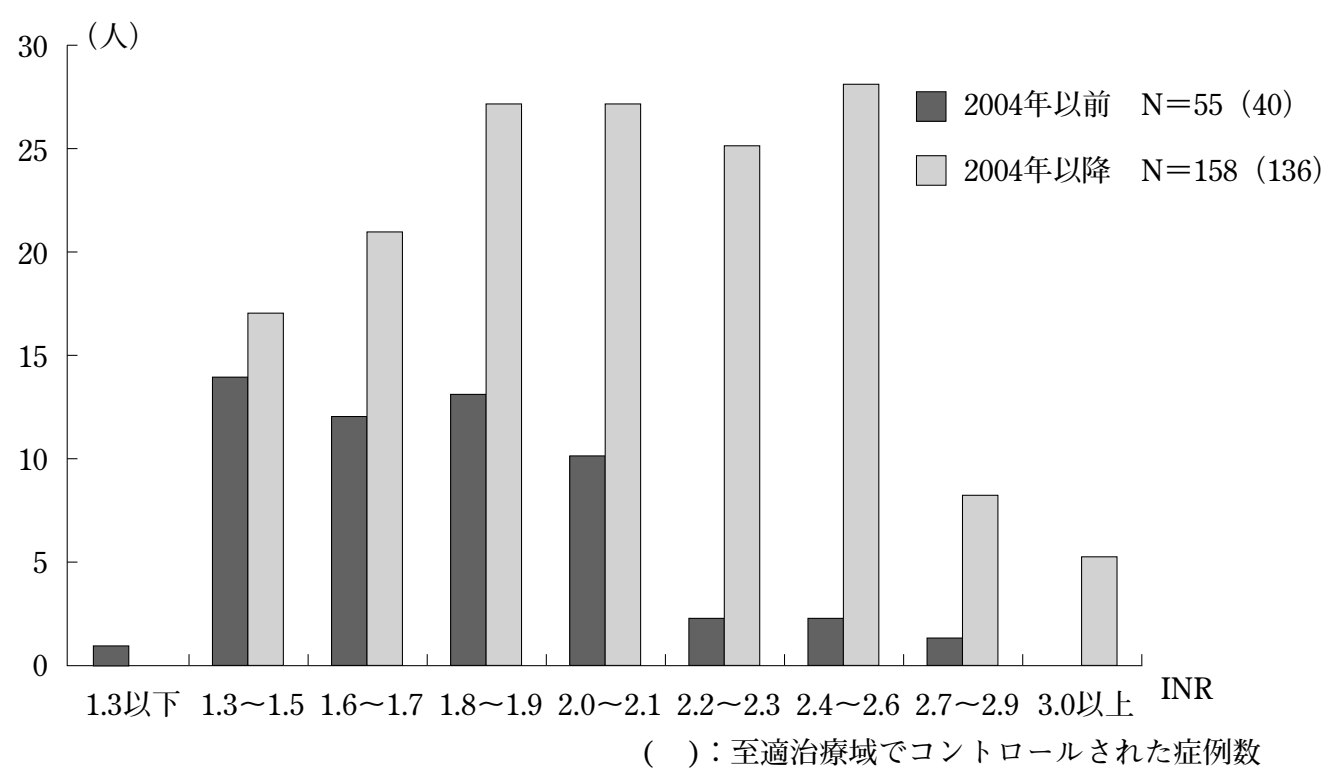

図 2 対象症例の初診時または抜㐘前 1 か月以内の抜柬前 INR

Fisherの直接確立計算法を用い検定した. $\mathrm{p}<0.05$ を有意 と判断した。

本研究は, 当院倫理委員会の承認（九医セン管発第 3527 号) を受けたものである.

結 果

\section{1. 対象症例の抜歯前，抜歯時の INR 值の検討}

\section{·抜㐘前 INR 值について（図 2, 表 1)}

2004 年以前群，以降群の至適治療域（INR 1.6 3.0）に コントロールされた症例の割合は以前群 55 例中 40 例 $(72.7 \%)$ であり，以降群では 158 例中 136 例（86.1\%) で有意に増加していた $(\mathrm{p}=0.037)$. 平均 INR もそれぞれ 1.85，2.15で両群間に有意差を認めた（p<0.01）. 治療域 は 2004 年以前群では INR $1.6 \sim 1.9$ の症例が 55 例中 25 例 $(45.4 \%)$ を占め, $2.0 〜 3.0$ は 15 例 $(27.3 \%)$ であった. 2004 年以降群では INR $2.0 \sim 3.0$ の症例が 158 例中 88 例 (55.7\%）を占め，1.6〜 1.9 は 48 例 $(30.3 \%)$ であった. 凝固系の抑制が十分でないと考えられている ${ }^{12)}$ INR 1.5 以 下の症例は 2004 年以前群では 15 例 $(27.3 \%)$ に認められ たが，2004 年以降群では 17 例 $(10.8 \%)$ であった. INR が 3.0 を超える症例は 2004 年以降群で 5 例見られた。 その 内 $3.99,3.71$ を示した 2 症例は主治医と協議の上，至適治 療域を超えていたため抜柬前にワルファリンの服用を減量 した.

·抜㐘時の INR 值について（図 3, 表 1) 2004 年以前群では 55 例中 18 例 $(32.7 \%)$ が至適治療
表 1 対象症例の抜歯前, 抜歯時の平均 INR

\begin{tabular}{|c|c|c|}
\hline & 2004 年以前群 $(\mathrm{N}=55)$ & 2004 年以降群 $(\mathrm{N}=158)$ \\
\hline 抜 & $1.85 \pm 0.34(72.7 \%)$ & $2.15 \pm 0.26^{*}(86.1 \%$ 沶 $)$ \\
\hline 抜柬時INR & $1.48 \pm 0.05(32.7 \%)$ & $2.03 \pm 0.23 *(77.8 \%$ 弥抣 $)$ \\
\hline
\end{tabular}

$(\%)$ : 至適治療域でコントロールされた症例の割合 $* \mathrm{p}<0.01$ (VS 2004 年以前群), 它 $\mathrm{p}<0.05$ (VS 2004 年以 前群)，记放 $\mathrm{p}<0.01$ (VS 2004 年以前群)

域内で抜柬され，平均 INR は 1.48 であった. 以降群では至 適治療域内で抜菌された症例は 158 例中 123 例 $(77.8 \%)$ であり以前群に比べ増加していた（ $\mathrm{p}<0.01)$. また，平均 INR も以降群では 2.03 を示し有意に高くなっていた（ $\mathrm{p}<$ 0.01). 2004 年以前群ではワルファリンの服用を中止また は減量後抜柬した症例は 55 例中 37 例 $(67.3 \%)$ である. 1.3 〜 1.5 で抜㐘した症例が 27 例と最も多く $49.1 \%$ を占め ていた. 2004 年以降群ではワルファリン中止症例は抜柬時 INR 1.3 以下の 6 例中 5 例, $1.3 \sim 1.5$ の 25 例中 4 例の計 9 例のみであった. 中止した 9 症例のうち 7 例は, 抜菌前に ワルファリンの継続服用を指示したにもかかわらず患者の 自己判断で服用を中止した症例で，2 例は主治医の指示で 中止した症例であった. 抜菌前に INR が 3.0 を超える症例 が 5 例認められたが, 内 2 例は減量後に抜歯した. 残りの 3 例は服用継続下で抜柬した. 抜歯前の検査では $1.88,1.93$ と至適治療域であったが, 抜㐘前の測定で 4.79, 3.69 を示 


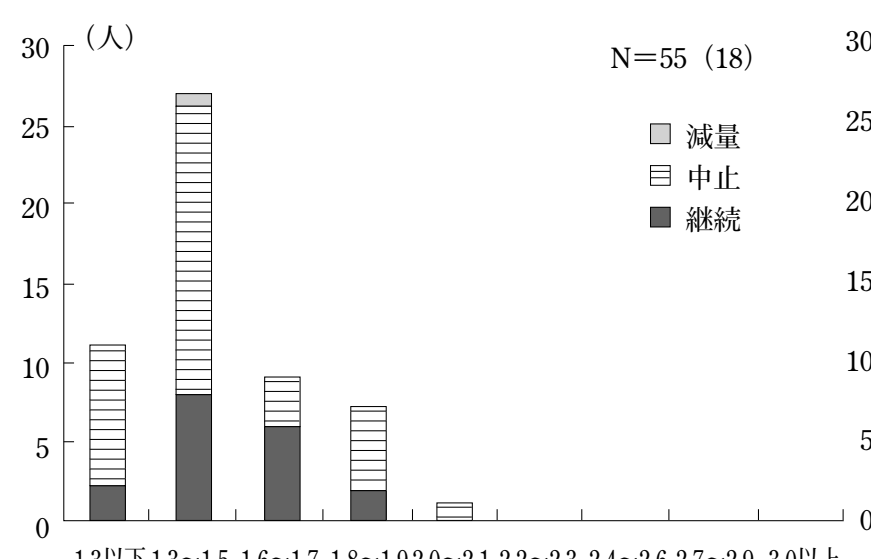

2004年以前群

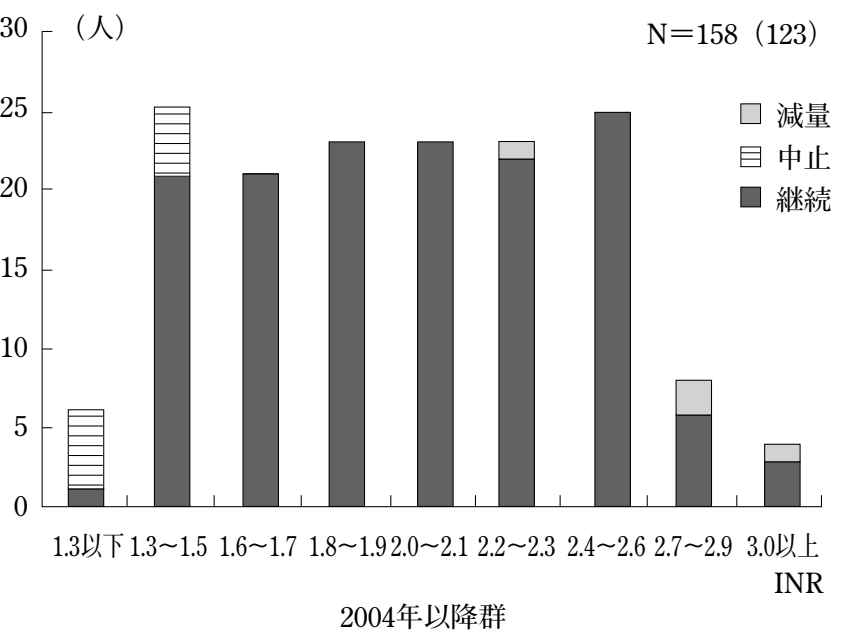

（）: 至適治療域でコントロールされた症例数

図 3 抜㐘時の INR

表 2 抜歯後出血

\begin{tabular}{|c|c|}
\hline 2004 年以前群 & $3 / 55$ 例 $(5.5 \%)$ \\
\hline $\begin{array}{l}\text { ワルファリン再開後 } 7 \text { 日目 } \\
\quad \text { (抜歯時 INR }: 1.58, \text { 出血時 INR : 2.39) }\end{array}$ & 圧迫，止血シーネにて止血 \\
\hline $\begin{array}{l}\text { ワルファリン再開後 } 7 \text { 日目 } \\
\quad \text { (抜菊時 INR }: 1.79, \text { 出血時 INR : } 2.33)\end{array}$ & 圧迫，止血シーネにて止血 \\
\hline 抜柬翌日（抜柬時 INR：1.31） & ガーゼ圧迫にて止血 \\
\hline 2004 年以降群 & $1 / 158$ 例 $(0.6 \%)$ \\
\hline 抜歯後 8 日目（抜柬時 INR：2.39） & $\begin{array}{l}\text { ワルファリン中止, 再縫合, } \\
\text { 粘膜保護材にて止血 }\end{array}$ \\
\hline 至適治療域内で抜柬 & $2 / 141$ 例（1.4\%） \\
\hline 至適治療域以外で抜歯 & $2 / 72$ 例 $(2.8 \%)$ \\
\hline
\end{tabular}

表 3 合併症の発現

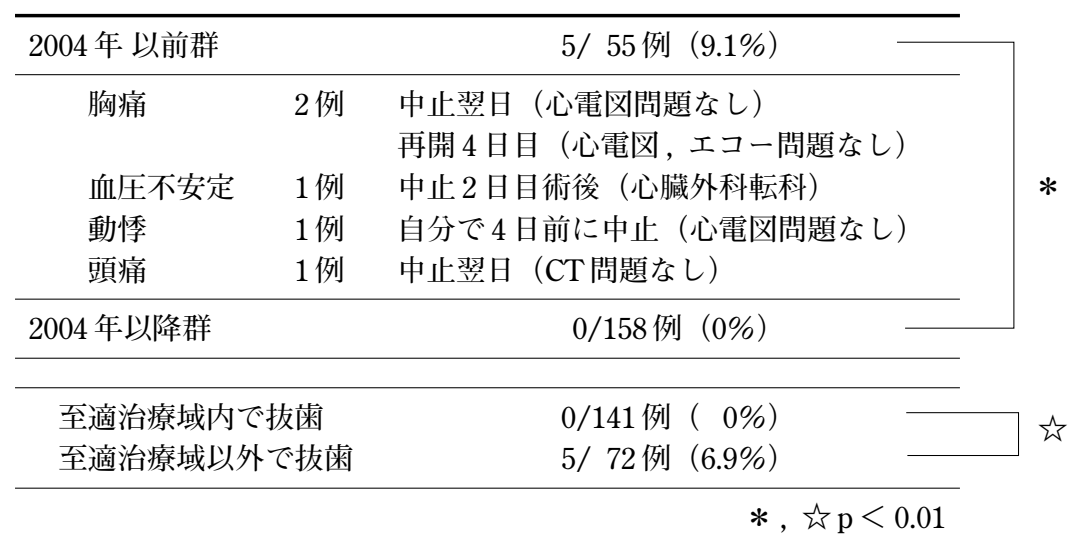


した症例があり，服用を減量し $2.37,2.66$ で抜茵した。

\section{2. 抜歯後出血と合併症について（表 2，3）}

抜菌後出血は，至適治療域内で行った 141 例中 2 例 $(1.4 \%)$, 至適治療域外での 72 例中 2 例 $(2.8 \%)$ に認め られたが両群に有意差はなかった $(\mathrm{p}=0.605) .2004$ 年以 前群と以降群では以前群で 3 例 $(5.5 \%)$, 以降群では 1 例 (0.6\%) 見られたが有意差はなかった $(\mathrm{p}=0.053) .2004$ 年以前群の 3 例は, ワルファリン中止症例で 1 例は前日に ワルファリンを中止し, INR 1.31 で行った症例であった. 2 例はワルファリン再開後 7 日目（INR が治療域に回復した 時期）に抜柬窩辺縁の㐘肉から出血が見られたため，ガー ゼ圧迫後，止血シーネを作製し止血した．継続症例の 1 例 は, INR 2.39 で抜茵を行い, 術直後の止血は問題なかった. しかし抜系後翌日の術後 8 日目に grade 2 の出血が認めら れた，その後，創部の治癒不全を起こし，出血が止まらず ワルファリンを中止し, 再縫合の上粘膜保護材を使用し止 血した.

合併症は 2004 年以前群の症例で胸痛 2 例，血圧不安定， 動悸，頭痛がそれぞれ 1 例ずつ計 5 例 $(9.1 \%)$ 認められ たが, 2004 年以降群では見られなかった. 合併症の発現は いずれも抜菌前は至適治療域にコントロールされており， ワルファリンを中止・減量後至適治療域以下で抜菌を行っ た症例である. 2004 年以前群 $(\mathrm{p}<0.01)$, 至適治療域以外 $(\mathrm{p}<0.01)$ での抜茵症例で発現が有意に高くなっていた. ただし，脳梗塞などの血栓症，塞栓性疾患あるいは出血性 疾患を含む重要な合併症は認められなかった。

\section{考察}

2004 年に日本循環器学会から「循環器疾患に打ける抗 凝固・抗血小板療法に関するガイドライン」が公表され， 各疾患に対する日本人に適した治療域が示された ${ }^{10)}$. 人工 弁置換術後, 弁形成術後患者では, INR $2.0 \sim 3.0$, 心房細 動においては，血栓塞栓症のリスクのある 70 歳未満の患 者では INR $2.0 〜 3.0,70$ 歳以上打よびリスクを有さない 60 歳以上の患者では INR $1.6 〜 2.6$ を目標としている. 2008 年に日本循環器学会から公表された「心房細動治療 (薬物) ガイドライン改訂版」13) でもワルファリン至適治 療域に変更がないことから, INR $1.6 〜 3.0$ が日本人の至適 治療域と思われる.

本報告ではガイドラインが公表されるまでの 2004 年以 前群（2000 2003 年）と公表後の 2004 年以降群（2004 ～ 2008 年）でワルファリン服用患者の至適治療域でのコ ントロール状態, 抜菌前, 抜柬時の抗血栓効果を比較した。 抜茵前 INR はガイドライン公表後の 2004 年以降群では至
適治療域でコントロールされた症例の割合も増加し，治療 域が有意に高くなっておりガイドライン公表後原疾患に対 する抗凝固コントロールが厳密に行われるようになったこ とが推察された。

2004 年以前群は 55 症例中 37 例でワルファリンを中止 または減量して抜菌が行われ，穴の結果至適治療域内で抜

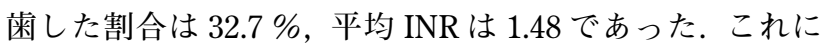
対し 2004 年以降群は 158 例中 144 例でワルファリン継続 投与下に $77.8 \%$ が至適治療域内で抜菌が行われ, 平均 INR は 2.03 で 2004 年以前群の 1.48 に比べ有意に高い状態であ ったが, 抜菌後出血の増加は認められなかった。このよう な結果から至適治療域 INR $1.6 \sim 3.0$ の範囲での抜㐘は安 全に行えると考えられた。

2004 年以降群で抜菌前に INR が 3.0 を超える症例が 5 例認められた. INR 3.0 以上での抜菌に関しては止血に問 題なかったが, 症例数が少ないためその安全性については 明確でない. 欧米では INRが 4.0 を越えての抜菌も行われ ており ${ }^{9)}$, INRによる後出血の発生率に差はないと報告も ある ${ }^{14)}$. しかし, 日本人は欧米人と比較して脳出血の頻度 が高い ${ }^{15)}$, 重篤な出血性合併症の発現が INR $2.2 \sim 3.5$ に コントロールした群で高いとの報告もあり ${ }^{16)}$, 欧米の基準 をそのまま日本人にあてはめることはできない. 抜茵当日 の検査で INR が 3.0 を超える症例は, 重篤な出血性合併症 の発現に注意すべきであり,ワルファリンの継続，中止に ついて主治医と十分協議の上，抜菌を行う必要があると考 える. また, INRが至適治療域にコントロールされていて も抜菌日に $4.79,3.69$ を示した症例もあり, 抜菌当日 INR を測定した上で処置を行うことが望ましいと思われた。

抜菌後出血は 4 例に認められたが, 1 例は抜菌時の INR は 1.31 と至適治療域以下で抗凝固効果は低くワルファリ ンの影響よりも掻爬不十分など手技的な影響が推測され る. 3 例は中止症例, 継続症例いずれも抗凝固状態が至適 治療域にある抜系後に出血している.このことは抗血栓療 法下では, 十分に器質化していない創部や菌肉に炎症があ ればちょっとした刺激で容易に出血し易い状態にあること を示している. 辺縁性柬周炎, う蝕の抜㐘では㐘肉縁部に 腫脹・発赤を伴っている場合が多く抜菌の際に菌肉縁部軟 組織の不良肉芽を十分掻爬し創部を小さく閉鎖することが 基本であるが，抜茵前の茵周治療による局所の炎症の管理 や抜茵後の食事, ブラッシング, 義茵の装着など患者への 生活指導も抜歯後出血を予防する上で必要であると思われ た.

ワルファリン服用継続下での抜茵に関しては, 当病院に て取り決めたワルファリン休薬下での抜㐘と比較して INR $1.6 \sim 3.0$ で抜菌後出血は増加していないこと, 2004 年以 前群でワルファリン服用中止後至適治療域以下の症例で胸 
痛, 頭痛などの症状が 5 例起こっていることを考慮すると， 至適治療域にコントロールされている患者ではワルファリ ンは中止せず，継続投与下での抜茵が望ましいと考えられ た. 今回の症例にはワルファリンの服用継続を指示したに もかかわらず，自己判断で中止した症例，主治医からの指 示で中止した症例も認められた. 矢坂らは, 抗血栓療法継 続下での抜柬の受け入れは，ワルファリンを投与する医師 側にも意見の統一がなされておらず，中止を求める医師も 存在することを報告しており ${ }^{17,18)}$ ，今後，医科との連携に おいて至適治療域内でのワルファリン継続投与下での抜㐘 の安全性をさらに示していく必要があると思われた.

\section{結語}

日本循環器学会 2004 年のガイドラインが示す至適治療 域は INR 1.6 から 3.0 である. 今回の結果からこのガイド ラインに従った抜柬で重篤な抜柬後出血は認めなかった. 至適治療域に管理されていても INRが変動することがあ り, 抜柬当日の INR 值は重要である. INRが 3.0 を超える 症例では，重篤な出血性合併症の発現を予防するため, ワ ルファリンの継続，中止について主治医と十分協議の上， 抜㐘を行う必要があると考える.

本論文の要旨は第 51 回日本口腔外科学会総会（2006 年 10 月，北九州市）において発表した.

\section{引用 文 献}

1) Yasaka, M., Naritomi, H., et al.: Ischemic stroke associated with brief cessation of warfarin. Thoromb Res 118: 290-293 2006

2) Wahl, M.J.: Dental surgery in anticoagulated patients. Arch Inter Med 158: 1610-1616 1998.

3) Morimoto, Y., Niwa, H., et al.: Hemostatic management of tooth extraction in patients on oral antithrombotic therapy. J Oral Maxillofac Surg 66: 51572008 .

4）牧浦倫子, 矢坂正弘, 他: 抗凝固療法中患者の抜茵 当日の出血管理. 脳卒中 $27:$ 424-427 2005 .

5）森本佳成, 丹羽 均, 他：抗血栓療法施行患者の抜
㐘における出血管理に関する検討。口科誌 53: 74-80 2004.

6）北村竜一：ワーファリン服用患者の抜柬一非中断症 例の検討一。日職災医誌 52: 65-67 2004.

7) Giovanni, B.F., Stefano, C., et al.: Oral surgery in patients on anticoagulant treatment without therapy interruption. J Oral Maxillofac Surg 65: 1149-1154 2007.

8) Scully, C., Wolff, A., et al.: Oral surgery in patients on anticoagulant therapy. Oral Surg Oral Med Oral Pathol 94: 57-64 2002.

9) Evans, I.L., Sayers, M.S., et al.: Can warfarin be continued during dental extraction ? Results of a randomized controlled trial. Br J Oral Maxillofac Surg 40: 248-252 2002.

10）循環器疾患における抗凝固・抗血小板療法に関する ガイドライン. Circ J 68（Suppl IV) : 1153-1219 2004.

11）新美直哉, 各務秀明, 他: 抗凝固療法施行患者の抜 㐘における出血管理について一線状アテロコラーゲ ンの使用経験. 日口外誌 46: 445-447 2000.

12) Lip, G.Y., Lip, P.L., et al.: FibrinD-dimmer and betathrombogenesis and platelet activation in atrial fibrillation: Effects of introduction ultra-low- Dose warfarin and aspirin. Circulation 94: 425-431 1996.

13）心房細動治療（薬物）ガイドライン（2008 改訂版） Circ J 72 (Suppl IV): 1603-1607 2008.

14) Blinder, D., Manor, Y., et al.: Dental extractions in patients maintained on oral anticoagulant therapy: Comparison of INR value with occurrence of postoperative bleeding. Int J Oral Maxillofac Surg 30: 5185212001.

15) Ueda, K., Hasuo, Y., et al.: Intracerebral hemorrhage in a Japanese community, Hisayama: incidence, changing pattern during long-term follow-up, and related factors. Stroke 19: 48-52 1988.

16) Yamaguchi, T.: Optimal intensity of warfarin therapy for secondary prevention of stroke in patients with nonvalvular artial fibrillation: a multicenter, prospective, randomized trial. Stroke 31: 817-821 2000.

17）矢坂正弘, 岡田 靖, 他 : 観血的な医学的処置時の 抗血栓療法の管理に関する研究一全国アンケート調 查結果一. Brain Nerve 59: 871-876 2008.

18）矢坂正弘, 岡田 靖, 他：福岡市内の病院勤務医 師・菌科医師を対象とする抜茵時の抗血栓療法に関 するアンケート調査. 脳と神経 58: 857-863 2006. 